\section{Are the Central East European Countries Pollution Havens?}

\author{
Inmaculada Martínez-Zarzoso', \\ Martina Vidovic ${ }^{2}$, and Anca M. Voicu ${ }^{2}$
}

Journal of Environment \&

Development $0(0) \mathrm{I}-26$

(C) The Author(s) 2016

Reprints and permissions: sagepub.com/journalsPermissions.nav DOI: $10.1 \mid 77 / 1070496516670196$ jed.sagepub.com

(SAGE

\begin{abstract}
The aim of this article is to investigate the relationship between environmental stringency and intra-European Union (EU) trade flows. Two main hypotheses are tested. First, we test whether the stringency of a country's environmental regulations may result in pollution havens. Second, we test whether the results differ by industry and by the EU membership tenure (EU- 15 vs. the newly added Central East European Countries). An augmented gravity model is estimated using panel data for $2 \mathrm{I}$ countries during the period from 1999 to 2013 for the full sample and also separately for the Central East European Countries and the EU-I5 members. Our results show weak support for the pollution haven hypothesis for some dirty industries, mainly for net exports from western EU countries to the rest. Instead, support for the "Porter hypothesis" is found for trade in clean goods.
\end{abstract}

\title{
Keywords
}

pollution haven hypothesis, Porter hypothesis, European Union, trade flows

The so-called pollution haven hypothesis $(\mathrm{PHH})$ predicts that trade liberalization will cause pollution-intensive industries to migrate from countries with stringent environmental regulations to countries with lax environmental regulations. The latter countries may have a comparative advantage in dirty goods and consequently attract foreign investment in their polluting sectors. ${ }^{1}$ Whether such pollution haven effects (PHE) exist is of great importance in the

\footnotetext{
'Department of Economics, University of Göttingen and University Jaume I in Castellón Platz der Göttinger, Göttingen, Germany

${ }^{2}$ Rollins College, FL, USA
}

\section{Corresponding Author:}

Martina Vidovic, Rollins College, 1000 Holt Avenue, Winter Park, FL 32789-4499, USA.

Email: mvidovic@rollins.edu 
present policy debates, since the existence of such effects could be a potential problem in negotiating integration agreements. In this sense, and concerning the most recent European Union (EU) enlargement, worries have been raised that the Central East European Countries (CEECs) could become pollution havens for dirty industries in Europe. This represents a concern particularly if the CEECs continue with policies of softer environmental regulations.

To the best of our knowledge, Jug and Mirza (2005) are the first authors who investigate the PHE in the European continent. They use a structural gravity equation and employ environmental expenditure data as the environmental stringency variable. They also follow the recent literature and argue that environmental regulations and trade are endogenous to each other. Since their investigation covers a brief time (e.g., 1996-1999), it cannot evaluate whether there has been a change in the interaction between trade flows and environmental regulation following the recent accession of CEECs into the EU in 2004 and 2007.

Using data from 1999 to 2013, our article aims to investigate the relationship between environmental stringency and export flows in the EU in order to determine whether the recent accessions of the CEECs into the EU and the subsequent changes in the regulatory framework of new members have affected intra-EU trade flows.

We test two main hypotheses. First, we test whether the stringency of a country's environmental regulations results in pollution havens or, on the contrary, it results in better export performance. Second, we test whether the results differ by industry (dirty vs. clean) and by the EU membership tenure (EU-15 vs. newly added EU member countries in 2004 and 2007). The question of whether more stringent environmental regulations harm or foster trade is relevant to the current debate regarding the $\mathrm{PHH}$ and its focus on the EU enlargement. The later has not yet been studied using disaggregated trade data and distinguishing between trade in dirty goods and trade in clean goods.

The remainder of the article is organized as follows; The following section presents the underlying theories and the related empirical studies on the relationship between trade and the environment. The third section outlines the theoretical assumptions behind the gravity model of trade, describes the data and the variables used, as well as our empirical strategy. The fourth section presents the main results, and the final section provides our conlcusions.

\section{Literature Review: The Trade and the Environment Debate}

There is a close and complex relationship between trade and the environment, and the effects of trade liberalization on the environment are rather mixed. This observation has led scholars to typically decompose the environmental impact of trade liberalization into the scale, technique, and composition effects 
(Antweiler, Copeland, \& Taylor, 2001; Cole \& Elliott 2003; Grossman \& Krueger, 1991; Lopez \& Islam, 2008; Stoessel, 2001). Furthermore, when trade is liberalized, all three effects work in tandem. The scale effect implies that holding the composition of trade and the production techniques constant, an increase in the scale of global economic activity due, in part, to international trade, leads to an increase in the total amount of pollution. Thus, trade liberalization has a negative impact on the environment. However, trade and growth are also credited with raising national incomes, and higher incomes cause citizens to demand high levels of environmental quality. Stricter environmental regulations provide incentives for firms to shift production toward cleaner goods. There is a great deal of evidence that higher incomes affect environmental quality in positive ways (Copeland \& Taylor, 2004; Grossman \& Krueger, 1991). This suggests that when assessing the effects of growth and trade on the environment, we cannot automatically hold trade responsible for environmental damage (Copeland \& Taylor, 2004). Since beneficial changes in environmental policy are likely to follow, the net impact on the environment remains unclear.

The technique effect predicts that changes in the production methods induced by trade liberalization have a positive impact on the environment. Researchers widely agree that trade is responsible for technology transfers. New technology is thought to benefit the environment if pollution per unit of output is reduced. Furthermore, if the scale of the economy and the mix of goods produced are held constant, a reduction in the emission intensity results in a decline in pollution.

According to the composition effect, trade liberalization will result in a country specializing in producing and trading goods in which it has a comparative advantage. The impact of the composition effect on the environment is not straightforward, and it depends on whether the source of a country's comparative advantage lies in a country's endowment of capital or labor or the stringency of environmental regulation. Four theoretical hypotheses have emerged concerning the nature of the composition effect associated with trade liberalization that led to different expectations.

First, the PHH states that differences in environmental regulations are the main motivation for trade. The hypothesis predicts that trade liberalization in goods will lead to a relocation of pollution intensive production from countries with high income and tight environmental regulations to countries with low income and lax environmental regulations. Developing countries, therefore, will have a comparative advantage in pollution intensive industries and become pollution havens. In this scenario, developed countries will gain, meaning that they will have a clean environment, while developing countries will lose, meaning that they will have a polluted environment).

Early empirical papers suggested that the stringency of environmental regulations had little or no impact on trade patterns (Grossman \& Krueger, 1991; Tobey, 1990; Xu, 2000). The argument was that, in general, pollution costs are 
relatively small with respect to total costs and multinational firms that operate in developed and developing countries do not want to be seen as transferring dirty operations to the latter countries. However, some studies have found weak evidence in support of PHH (Grether \& de Melo, 2003; Jug \& Mirza, 2005; Khan \& Yoshino, 2004; Mantovani \& Vancauteren, 2008). This finding coupled with additional sources of comparative advantages, such as labor costs differences, provides an extra reason to transfer production from rich to poor countries. Cole (2004) provided an excellent literature review and presents empirical evidence consistent with this view. Although we restrict our literature review to studies that examine the effects of environmental standards on trade flows, recent studies that examined the effect of regulations on foreign direct investment flows (see Ben Khedra and Zugravu, 2012; Dean, Lovely, \& Wang, 2009; Rezza, 2013; Wagner \& Timmins, 2009), or on the carbon leakage content of import flows (Aichele \& Felbermayr, 2012) found empirical support for the PHH. More recently, using data on the U.S. regulation and trade with Canada and Mexico, Levinson and Taylor (2008) showed that pollution control expenditures have important effects on trade flows. They suggest that aggregation issues, unobserved heterogeneity, country heterogeneity, and endogeneity can bias the results against finding support for the PHH. With respect to aggregation, Grether and de Melo (2003) and Mathys (2002) noted that an aggregate analysis hides specific patterns in each industry and hence may mask PHE in specific industries. They argue that if there is indeed a PHH story in the data, it is more likely to be found at the disaggregated level. Similarly, Ederington, Levinson, and Minier (2005) identified and tested three explanations that account for the lack of evidence for the PHH. These reasons are that (a) most trade takes place between developed countries; (b) some industries are less geographically footloose ${ }^{2}$ than others and, therefore, least likely mobile; and (c) for the majority of industries environmental regulation costs represent only a small fraction of total production costs. In all three cases, aggregated trade flows across multiple countries could conceal the effect of environmental regulation on trade for countries with distinct patterns of regulation, as well as for more footloose industries or for industries where environmental expenditures are significant. The authors find support for the first two explanations. On one hand, estimating the average effect of an increase in environmental costs over all industries understates the effect of regulatory differences on trade in more footloose industries and on trade with low-income countries. On the other hand, a study that uses disaggregated data might be problematic. For example, most cross-industry studies only examine dirty industry sectors (e.g., Tobey, 1990). Those industries could share some unobservable characteristics (e.g., natural resource intensiveness) that also make them immobile. Restricting the sample to pollution-intensive industries might lead to the selection of the least geographically footloose industries. For this reason, it is reasonable to examine the trade in clean sectors as well for a comparison because we would expect a different 
effect of pollution regulations on pollution-intensive sectors (or even to have the opposite sign) than on clean sectors (Brunnermeier \& Levinson, 2004).

Unobserved heterogeneity refers to unobserved industry or country characteristics, which are likely to be correlated with strict regulations and the production and export of pollution-intensive goods. Assume that a country has an unobserved comparative advantage in the production of a pollutionintensive good; consequently, it will export a lot of that good and will also generate a lot of pollution. Ceteris paribus, it will impose strict regulations to control pollution output. If these unobserved variables are omitted in a simple cross-sectional model, this will produce inconsistent results, which cannot be meaningfully interpreted (in this example, a simple cross-sectional model would find a positive relationship between strict regulations and exports). The easiest solution to this problem would be to use panel data, with time variation, and incorporate country or industry-specific fixed effects (Brunnermeier \& Levinson, 2004).

In addition, pollution regulations and trade may be endogenous to each other, that is, the causality might run in both directions (problem of simultaneous causality). If trade liberalization leads to higher income which in turn causes an increase in the demand for environmental quality, then environmental regulations may be a function of trade. A possible solution to this problem is to use instrumental variables techniques. However, the instruments should possess the following characteristics: vary over time and be correlated with the measure of environmental stringency but not with the error term (Brunnermeier \& Levinson, 2004).

The second hypothesis is the factor endowment hypothesis that claims that trade patterns are determined by differences in factor endowments and not by environmental policy. According to the factor endowment hypothesis, capital abundant countries will export capital intensive (dirty) goods since most polluting industries are also highly capital intensive (see, e.g., Antweiler et al., 2001; Mani \& Wheeler, 1997), and therefore, capital abundant countries will experience an increase in pollution. Countries, where capital is scarce, will see a fall in pollution given the contraction of the pollution-generating industries. Since higher income countries are more capital abundant than lower income countries, in the presence of trade liberalization, developed countries will specialize in capital-intensive, dirty industries, and developing countries will specialize in labor-intensive, relatively cleaner industries. This is opposite of what the $\mathrm{PHH}$ predicts, and thus, the actual impact of liberalized trade on the environment depends on the determinants of comparative advantages across countries. Studies by Antweiler et al. (2001) and Cole and Elliott (2003), using different measures of pollution, find evidence that both environmental regulations and relative capital-labor endowments determine the composition effect of free trade on the environment. After accounting for the scale, technique, and the composition effects, Antweiler et al. (2001) concluded that free trade is good for the 
environment. Cole and Elliott (2003) confirmed this overall claim only for some pollutants and only for pollution intensities data but not for the emissions data.

The race to the bottom is the third hypothesis, which asserts that developed countries refrain from adopting more stringent environmental regulations due to competition with countries that have lax environmental regulation (Esty \& Geradin, 1998; Stoessel, 2001).

Finally, the "Porter hypothesis" assumes a race to the top, meaning that strict environmental regulations have the potential to reduce costs and induce efficient use of resources while encouraging innovation that helps to improve competitiveness (Porter \& van der Linde, 1995; Stoessel, 2001). The hypothesis predicts that tightening of environmental regulation will have positive effects on the economy and the environment. Ambec and Barla (2006) followed the same line of thinking and argue that environmental regulations force managers to adopt profitable technologies earlier. While the "weak" version of the hypothesis states that stricter regulation leads to more innovation, the "strong" version states that stricter regulation enhances business performance. The empirical tests of the Porter hypothesis are mainly based on specific industries with certain characteristics that profit the most from stringent regulations. For example, Albrecht (1998) analyzed only industries affected by the Montreal Protocol and finds evidence supporting the Porter hypothesis for Denmark and the United States, whereas Murty and Kumar (2003) focused their analyses on water-polluting industries in India and also find weak support for the hypothesis. Ambec, Cohen, Elgie, and Lanoie (2011) provided a summary of theoretical and empirical studies on the Porter hypothesis. On the empirical side, the evidence for the weak version of the Porter hypothesis is fairly well established, while the empirical evidence on the strong version is mixed, with only recent studies supporting it. Most studies use productivity as the target variable with the exception of Constantini and Crespi (2008), who use exports of specific industries related to renewable energies and find support for the strong version of the hypothesis.

In summary, the literature identifies the existence of both positive and negative effects of pollution policy on trade and the environment. The positive effects include increased growth accompanied by the distribution of environmentally safe, highquality goods, services, and technology. The negative effects stem from the relocation of pollution-intensive economic activities to countries with lax environmental regulations that could potentially threaten the regenerative capabilities of ecosystems while increasing the danger of depletion of natural resources.

The gravity model of trade has often been used as a theoretical framework to empirically analyze the relationship between environmental regulations and trade flows and, in particular, to test for the existence of a PHH. Related research contributions are due to Harris, Kónya, and Mátyás (2002); Grether and de Melo (2003); van Beers and van den Bergh (1997); and Jug and Mirza (2005), who tested for the existence of a PHH using panel data and focus mainly 
Table I. Summary Statistics.

\begin{tabular}{|c|c|c|c|c|c|c|c|}
\hline \multirow[b]{2}{*}{ Variable } & \multicolumn{3}{|c|}{$\mathrm{EU}=0$} & \multicolumn{4}{|c|}{$\mathrm{EU}=\mathrm{I}$} \\
\hline & Obs & Mean & $S D$ & Obs & Mean & $S D$ & Test-diff \\
\hline $\begin{array}{l}\text { Dirty exports } \\
\text { (in millions) }\end{array}$ & 21,089 & 13.8 & 57.5 & 59,255 & 103 & 356 & 36.26 \\
\hline $\begin{array}{l}\text { Clean exports } \\
\text { (in millions) }\end{array}$ & 22,992 & 804 & 1650 & 61,582 & 5790 & 10600 & 70.79 \\
\hline $\begin{array}{l}\text { Total environmental } \\
\text { tax revenues }\end{array}$ & 22,992 & 8521.26 & $|4002.8|$ & 61,582 & |5959.9| & $17|83.9|$ & 58.76 \\
\hline GDP & 22,992 & 325654.1 & 548955.5 & 61,582 & 629149.7 & 710729.1 & 58.56 \\
\hline
\end{tabular}

Note. Test difference reports $t$ statistics for the difference in means. See Table A3 for variable descriptions.

on developed countries. The results are not unambiguous and produce, at best, weak evidence in favor of the PHH. This is confirmed by a metaanalysis provided by Mulatu, Florax, and Withagen (2004). Of all these studies, only Jug and Mirza's (2005) empirical application was based on a structural gravity equation that is well theoretically founded. The authors also summarize the main findings of previous studies investigating the impact of environmental regulations on trade using sectoral data (Table 1, p. 5). Jug and Mirza (2005) concluded that none of the studies using the gravity model of trade finds a robust link between environmental standards and trade and that studies focusing on the United States claim that endogeneity is the main reason why previous studies did not find an effect.

We have chosen to use the gravity model in this article because it is a wellestablished trade model with solid theoretical foundations. It also permits the tackling of the aforementioned econometric problems of endogeneity, unobservable heterogeneity, and aggregation issues. To investigate the presence of pollution haven on the European continent, we follow Levinson and Taylor (2008) and control for unobserved characteristics of industries and locations and consider that pollution regulation and trade may be endogenous to each other.

\section{Theoretical Background, Model Specification, Data, and Variables}

\section{Theoretical Background and Model Specification}

The gravity model of trade is nowadays the most commonly accepted framework to model bilateral trade flows (Anderson, 1979; Anderson \& Van Wincoop, 2003; Bergstrand, 1985). 
Independent from the theoretical framework of reference, most of the mainstream foundations of the gravity model are variants of the Anderson (1979) demand-driven model, which assumes a constant elasticity of substitution and product differentiation by origin. According to the underlying theory, trade between two countries is explained by nominal incomes, by the distance between the economic centers of the exporter and importer and by trade costs usually proxied with a number of trade impeding and trade facilitating variables, such as trade agreements, common language, or a common border.

According to the underlying theory that has been reformulated and extended by Anderson and van Wincoop (2003), the model assumes a constant elasticity of substitution and product differentiation by place of origin. In addition, prices differ among locations due to symmetric bilateral trade costs. The reduced form of the model is given by

$$
X_{i j k t}=\frac{Y_{i t} Y_{j t}}{Y_{t}^{W}}\left(\frac{t_{i j t}}{P_{i t} P_{j t}}\right)^{1-\sigma},
$$

where $X_{i j k t}$ are bilateral exports of product $k$ from country $i$ to country $j$ in year $t$, and $Y_{i t}, Y_{j t}$, and $Y_{t}^{W}$ are the gross domestic products (GDPs) in the exporting country, the importing country, and the world in year $t$, respectively. $t_{i j t}$ denotes trade cost between the exporter and the importer in year $t$, and $P_{i t}$ and $P_{j t}$ are the socalled multilateral resistance terms. $\sigma$ is the elasticity of substitution between goods.

The empirical specification of the model in Equation 1 in log-linear form is given by

$$
\ln X_{i j k t}=\ln Y_{i t}+\ln Y_{j t}-\ln Y_{t}^{W}+(1-\sigma) \ln t_{i j t}+(1-\sigma) \ln P_{i t}+(1-\sigma) \ln P_{j t} .
$$

The estimation of Equation 2 is not straightforward, since some assumptions are required, concerning the trade costs and multilateral resistance terms. The trade cost function is assumed to be a linear function of a number of trade barriers, namely, the time invariant determinants of trade flows such as distance, common border, common language, and whether a country is landlocked.

Substituting the trade cost function into Equation 2 suggests estimating

$$
\begin{aligned}
\ln \left(X_{i j k t}\right)= & \alpha_{0}+\alpha_{1} \ln Y_{i t}+\alpha_{2} \ln Y_{j t}+\alpha_{3} \ln D_{i j}+\alpha_{4} \text { Landl }_{i}+\alpha_{5} \text { Landl }_{j} \\
& +\alpha_{6} \text { Border }_{i j}+\alpha_{7} E U_{i j t}+u_{i j k t},
\end{aligned}
$$

where $D_{i j}$ denotes geographical distance from country $i$ to country $j$; $L a n d l_{i}$ and Land $_{j}$ take the value of one when countries $i$ or $j$ are, respectively, landlocked, 0 otherwise; Border $_{i j}$ takes the value of one when the trading countries share a border, 0 otherwise; and $E U_{i j t}$ takes the value of one when the trading countries are members of the EU, 0 otherwise. Based on the recent gravity literature, 
the multilateral resistance terms are modeled as country-pair-specific dummies. That prevents us from obtaining the coefficient estimates for time-invariant variables, and their effects are subsumed into the country-pair dummies.

The gravity model has been widely used to investigate the role played by specific policy or geographical variables in explaining bilateral trade flows. Consistent with this approach, and in order to investigate the effect of environmental regulations on exports, we augment the model with proxies for the differences in environmental regulations between countries and use net exports as the dependent variable. Introducing several sets of fixed effects, the specification of the gravity model is

$$
\ln \left(\text { net } X_{i j k t}\right)=\theta_{k t}+\delta_{i j}+\alpha_{1} \ln Y_{i t}+\alpha_{2} \ln Y_{j t}+\alpha_{3} \ln \text { Etaxdif }_{i j t}+\alpha_{4} E U_{i j t}+\eta_{i j k t},
$$

Net $X_{i j k t}$ is net exports of industry $k$ from country $i$ to country $j$ at time $t$; $E U_{j i t}$ is a dummy variable that takes the value of 1 when countries $i$ and $j$ belong to the EU, 0 otherwise;

Etaxdif $f_{i j t}$ denotes the difference in the environmental stringency calculated as the difference between the total environmental tax revenues between countries $i$ and $j$ (in current $€$ );

$Y_{i t}$ and $Y_{j t}$ denote the GDPs in the exporting country and the importing country in year $t$ in current $€$.

The dummy variable for the EU integration is time-varying since Eastern European countries joined the EU at different times during the period studied. $\theta_{k t}$ are specific industry-time effects that control for omitted variables specific to each industry export flows but which vary over time. $\delta_{i j}$ are bilateral-specific fixed effects that proxy for multilateral resistance factors.

Although some authors suggest that exporter and importer fixed effects should be time varying, we cannot include them in the estimation because they are correlated with the variables of interest. Instead, we use industry-specific time-varying fixed effects to proxy for the dynamics of specific factors that affect sectoral competitiveness in all countries. We estimate the model by replacing the time-invariant bilateral variables, such as distance and common border with dyadic fixed effects to control for unobserved heterogeneity. Hence, the influence of the variables that vary only with the $i j$ dimension cannot be directly estimated. This is the case for distance and common border; therefore, their effects are subsumed in the dyadic dummies.

The expected signs for the coefficients of the variables included in the model are based on the theory. A high level of income in the exporting country indicates a high level of production, which increases the availability of goods for export. Therefore, we expect $\alpha_{1}$ to be positive. The coefficient on $Y_{j}$, $\alpha_{2}$, is also 
expected to be positive, since a high level of income in the importing country suggests a higher demand for imports.

The expected sign for the coefficient on the environmental stringency difference is also not unambiguous. According to the PHH, we expect the sign to be negative. Stricter environmental standards will increase the cost of production and result in higher prices of domestically produced goods relative to foreign goods leading to a decrease in net exports. For dirty industries, the stringency of environmental regulation will imply a loss of competitiveness and lower net exports of dirty goods. However, the Porter hypothesis states that the sign on the environmental stringency variable should be positive. According to Porter and Van der Linde (1995), stringent environmental regulations can lead to a development of comparative advantage in highly regulated industries. Other reasons for a positive effect include technology spillovers as well as consumer demand for "green" goods in the trading partner countries.

We estimate the gravity model for "clean" trade flows and for exports by specific dirty industries for which the impact should be stronger, according to the related literature. Following Low and Yeats (1992), Tobey (1990), van Beers and Van der Bergh (1997), Xu (1999), Harris et al. (2002) and Arouri, Caporale, Rault, Sova, and Sova (2012), we classified industries into dirty and footloose categories based on the SITC (version 3). According to Low and Yeats, pollution-intensive industries are those for which incurred pollution abatement and control costs are $1 \%$ or more of total costs. The following industries are classified as "dirty" 51 (organic chemicals), 52 (inorganic chemicals), 59 (chemical materials), 64 (paper, paperboard), 67 (iron and steel), 68 (nonferrous metals), and 69 (metals manufactures), 251 (pulp and waste paper), 334 (petroleum products), 335 (residual petroleum products), 562 (fertilizers), 634 (veneers, plywood), 635 (wood manufactures), 661 (lime, cement, construction materials). Within the dirty category, industries $59,67,69$, and 661 are classified as pollution intensive "footloose" industries because these sectors do not depend on resources and can easily relocate. It is expected that if environmental regulations have a real impact on international trade flows, their impact should be the strongest for exports by dirty industries and in particular for exports by "footloose" industries. To be able to compare our findings to the studies cited earlier, we followed the same classification of footloose industries, noting that cement may not be a footloose industry because of its high transport cost (see Ederington et al., 2005). Table A1 presents the description of each industry and the corresponding emissions intensities.

\section{Data and Variables}

We examine export flows for a panel of 21 EU countries from 1999 to 2013, the latest year for which complete data are available. Table A2 provides a list of countries and the years when the Eastern European countries joined the EU. 
Data on total and sectoral bilateral trade flows are from the UN COMTRADE. GDPs at current prices are from Eurostat. Other gravity variables, such as common border, common language, and distances come from CEPII, but they are dropped from the final model because they are time invariant.

For the environmental stringency variables, we use a new version of Eurostat's Environmental Expenditures and Environmental Taxes database. Eurostat collects data through a Joint Eurostat and Organisation for Economic Co-operation and Development questionnaire on Environmental Protection Expenditure and Revenues. Data include all sectors of the economy and allow for a temporal comparison among the EU countries. As the main proxy for regulatory stringency, we use total environmental tax revenues. This variable is comparable to that used by recent studies (Ben Kheder \& Zugravu, 2012; Constantini \& Crespi, 2008).

A major obstacle for empirical studies assessing the linkage between trade and the environment is lack of direct measure of the stringency of environmental regulation. According to Brunel and Levinson (2016), one challenge in measuring the stringency of environmental regulation is the issue of multidimensionality, which reflects that regulations differ by medium, pollutant, sector, and the nature of enforcement. The authors also mention the issue of simultaneity where regulatory stringency is both influencing and influenced by the emissions of pollutants. To tackle multidimensionality, most researchers considered a single environmental policy variable, which makes their findings difficult to generalize. Simultaneity can be addressed using the instrumental variable techniques.

The types of measures used in the empirical literature to represent environmental stringency have been either survey based or have focused on total expenditures at a country level or at a sectoral level. Good examples of recent studies that focus on survey indicators are Spatareanu (2007), Wagner and Timmins (2009), Kellenberg (2009), Manderson and Kneller (2012), and Rezza (2013) who used the Executive Opinion Survey published at the Global Competitiveness Report, which surveys business executives on environmental issues and measures the overall stringency of environmental regulations and enforcement on a scale from 1 to 7 . The advantage of this measure is that it allows for a comparison of a broader number of countries outside the EU. However, on the negative side, the construction of the indicators depends on the perceptions of survey respondents, and survey questions have not been consistent over the years, which make comparisons over time unfeasible.

Examples of proxies for environmental stringency based on expenditures include public expenditures for environmental protection (Magnani, 2000; Pearce \& Palmer, 2001), pollution abatement control expenditures (Cole, Elliott, \& Shimamoto, 2005; Ederington \& Minier, 2003; Levinson \& Taylor, 2008; Marconi, 2012), or current environmental protection expenditures by industry as a percentage of GDP (Constantini \& Crespi, 2008; Jug \& Mirza, 2005). A disadvantage of using public-sector expenditures is that their increase 
can potentially reduce investment by the private sector in protecting the environment, and it is not guaranteed that they will result in stricter regulations. While the pollution abatement control expenditures directly reflect the expenditures on the protection of the environment by firms, their drawback is that they include all abatement costs, which makes it difficult to separate the abatement costs due to regulatory stringency from all other abatement costs. Furthermore, there may be incentives to overstate or understate the abatement costs by firms. Current environmental protection expenditures cover spending on activities that are directly aimed at the prevention, reduction, and elimination of pollution or any other degradation of the environment and, as such, are a reasonable candidate for measuring the stringency of regulation. We have also considered this variable, but the data are incomplete. Hence, we opted for the total environmental tax revenues data provided by Eurostat because they are directly related to the production processes, and the associated costs incurred by firms to abate pollution. They also correspond to the common European environmental regulation reflecting equal environmental standards for all EU members. Brunel and Levinson (2016) cautioned that for the same level of regulatory stringency, the control costs may vary due to differences in the costs of inputs to pollution abatement, firm heterogeneity, the country's geographic location, level of development, market imperfections, or access to technology. Changes in environmental taxes must also be interpreted with caution. The increases may be caused by the introduction of new taxes or an increase in tax rates, or alternatively may be linked to an increase in the tax base. Any investment in pollution reduction lowers taxes and firms benefit from less scrutiny from the government.

Figure 1 shows the evolution over time of environmental tax revenues as a share of GDP for the CEECs included in our sample. Some convergence toward lower average values can be observed for the period under study.

Table 1 displays the summary statistics for the independent and dependent variables for non-EU countries and EU groups of countries. The last column shows the results of a test of the differences in the mean for each variable between the two groups. These differences are statistically significant for all variables. In general, EU membership is associated with higher exports of both dirty and clean goods and higher GDPs. Also, environmental tax shares are significantly higher for the EU members than for non-EU member states.

Table 2 displays the bivariate correlation coefficients for the variables in our study. Environmental stringency is negatively associated with the exports of both dirty and clean products and with the GDP in the importing countries but positively with the GDP of exporting countries.

\section{Main Results}

The first estimation results based on Model 4 are reported in Table 3 . Columns 1 and 2 show the results obtained for dirty exports and for footloose industries, 


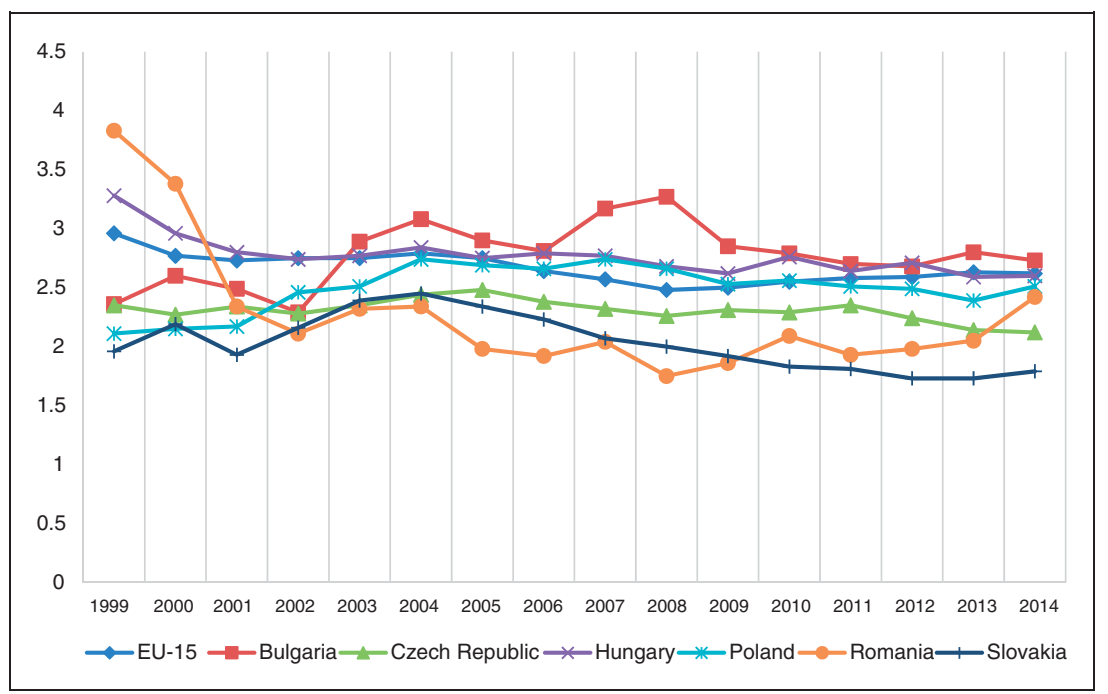

Figure I. Trend in total environmental tax revenues, percent of GDP. Source. Author's elaboration using data from Eurostat.

Table 2. Correlation Coefficients.

\begin{tabular}{lccccc}
\hline & Ln(dirty exports) & $\operatorname{Ln}($ clean exports) & $\operatorname{Ln}\left(\mathrm{GDP}_{i}\right)$ & $\operatorname{Ln}\left(\mathrm{GDP}_{j}\right)$ & $\mathrm{EU}$ \\
\hline $\operatorname{Ln}($ clean exports) & 0.562 & & & & \\
$\operatorname{Ln}\left(\mathrm{GDP}_{\mathrm{i}}\right)$ & 0.347 & 0.469 & & & \\
$\operatorname{Ln}\left(\mathrm{GDP}_{\mathrm{j}}\right)$ & 0.427 & 0.529 & -0.034 & & \\
EU dummy & 0.334 & 0.403 & 0.273 & 0.518 & \\
Ln(environmental & -0.109 & -0.097 & 0.638 & -0.771 & -0.228 \\
$\quad$ & & & & & \\
\hline
\end{tabular}

Note. All correlations are statistically significant at the $\mathrm{I} \%$ level. EU is a dummy variable equal to $\mathrm{I}$ if a country is a member of the European Union; 0 otherwise.

column 3 for clean exports. Regarding our target variable, namely, exporters' environmental tax revenue difference (Etaxdif), the results indicate a positive correlation between the former variable and net exports for dirty and clean goods. However, the coefficient is only statistically significant for clean exports. This implies that stricter environmental regulations stimulate trade in clean goods.

The coefficients on the exporter's and importer's incomes are positive and significant in most cases and different from the theoretical value of unity.

The EU dummy for membership in the integration agreement is positive and significant, indicating that exports are higher for participating countries than for 


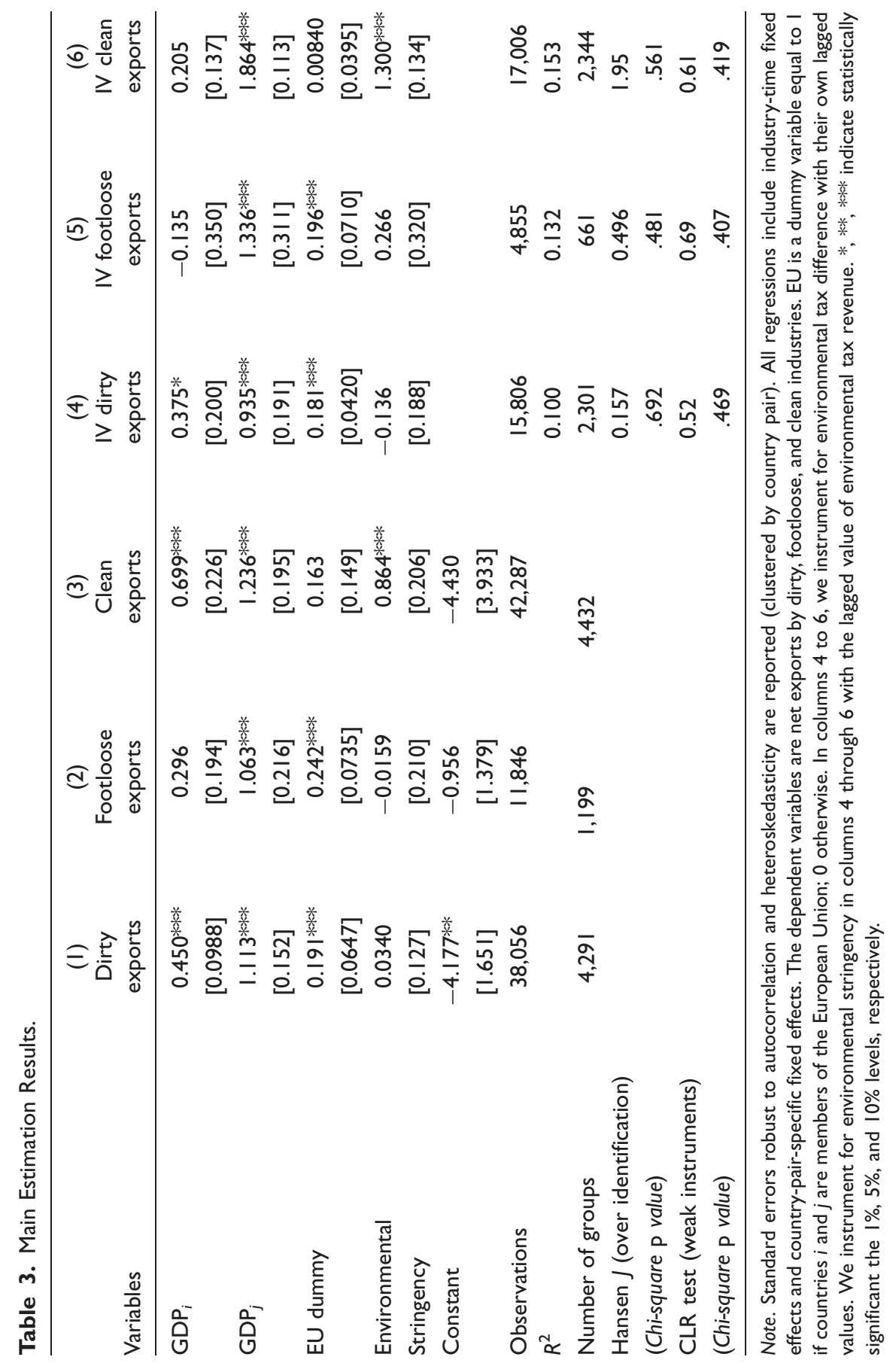


the rest of the countries in the sample but only for dirty and footloose goods but not for clean goods.

We obtain similar results when we use an instrumental variable estimator to control for the endogeneity of the environmental variables as shown in columns 4 to 6 in Table 3. The instruments used are the lagged values of the variable of interest (we also tried first and second lag of total tax revenues and obtained similar results). We first assess the relevance and validity of our instruments. Effective instruments must satisfy two conditions: They must be correlated with the included endogenous variables (relevant), and they must be orthogonal to the error term (valid). Using the Sargan-Hansen statistic (for over identification), we fail to reject the null hypothesis that the instruments are jointly uncorrelated with the errors given $p$ values of .692, .481, and .561, respectively. Using a Conditional Likelihood Ratio test (for weak instruments), we fail to reject the null hypothesis that the excluded instruments are correlated with the included endogenous regressors given the $p$ values of $.469, .407$, and .419 , respectively. Based on our assessment, the instruments are both relevant and valid.

The environmental stringency variable of interest has the same significance level, but the magnitude of the estimated coefficient for the exporters' environmental tax expenditure difference is slightly higher for clean goods in comparison to the results in column 3 in Table 3. According to the results in column 6 , a $10 \%$ increase in environmental taxes is associated with a $13 \%$ increase in net exports of clean goods.

To investigate whether the results differ by industry and region and whether this heterogeneity is the reason why we obtain nonsignificant coefficients on the environmental stringency variable, we run similar regressions for the EU-15 countries and the CEECs and for each dirty industry separately. Hence, we run regressions with sector-specific slope coefficients to see whether there is heterogeneity within the dirty industries that is affecting the estimated coefficients. Table 4 reports the estimation results for the environmental expenditure differences variable. Again, we instrument for environmental stringency with lagged values. The instruments are both relevant and valid. The results for the relevance and the validity of instruments are reported in Tables A4 to A6. We find that for the EU-15 countries higher differences in environmental revenues between partner countries are associated with lower net exports of dirty goods for seven major polluter industries, namely, for chemical materials, paper and paperboard, metal manufactures, petroleum products, fertilizers, wood manufacturers, and lime, cement, and construction materials. This happens only for two industries when the CEECs are considered as exporters (fertilizers and wood manufacturers). The estimated coefficient of the target variable is not statistically significant for other industries possibly because these industries contain a range of products that are still too heterogeneous.

Summarizing, while higher differences in environmental tax revenues are positively correlated with clean exports, they are negatively correlated with exports 


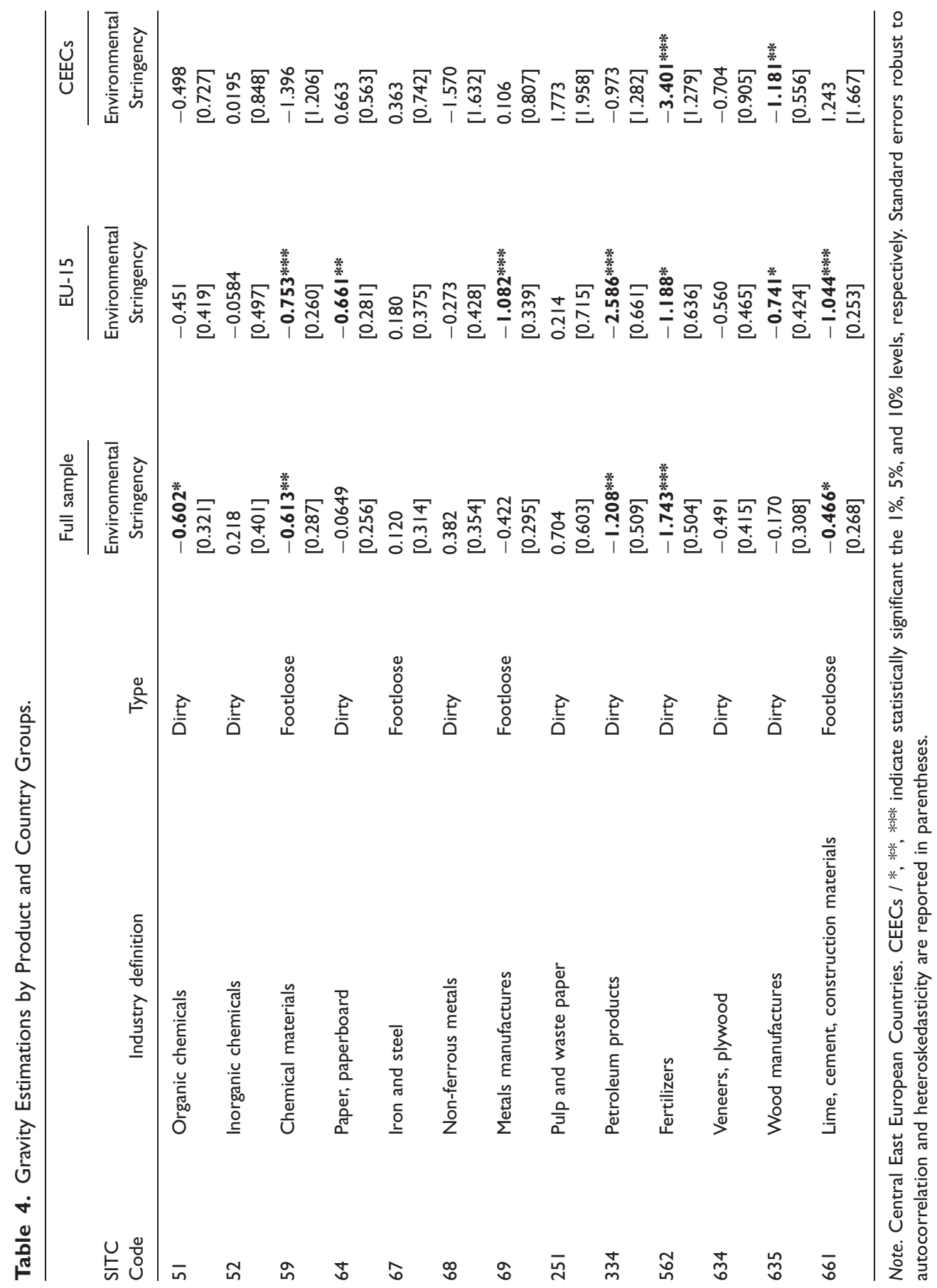


of some dirty and footloose industries. Hence, we find some evidence supporting the Porter hypothesis for clean exports and only some evidence of the $\mathrm{PHH}$ for specific footloose and dirty industries.

\section{Conclusion and Policy Recommendations}

This article contributes to the debate of whether environmental regulations influence patterns of international trade. We investigate whether changes in the stringency of a country's environmental regulations result in pollution havens, in particular in relation to trade flows within the European continent from 1999 to 2013, covering, therefore, the recent accession of the CEECs into the EU and the subsequent changes in the regulatory framework of new members. We empirically assess the relationship between environmental stringency and export flows by estimating a gravity model of trade augmented with environmental tax revenue variables.

Using panel data and instrumental variables techniques, we find that environmental stringency variables are an important determinant of clean bilateral exports and of specific dirty and footloose industries' exports. More specifically, while exporters' environmental tax revenue differences are positively correlated with bilateral net exports of clean industries, the effect of environmental stringency differences on net exports of dirty industries is not significant when all the industries are treated as a homogeneous group. The results are robust to a variety of specifications for the particular variables used in the estimation, namely, to the use of different type of fixed effects to control for unobserved heterogeneity.

However, when heterogeneity across specific industries and between two groups of countries is considered, the results differ. We find that for the EU-15 countries higher differences in environmental revenues between partner countries are associated with lower net exports of dirty goods for seven major polluter industries, namely for chemical materials, paper and paperboard, metal manufactures, petroleum products, fertilizers, wood manufacturers, and lime, cement, and construction materials. However, when the CEECs are considered as exporters, the same phenomenon happens for two industries only (fertilizers and wood manufacturers).

Summarizing, the empirical results show that for Western EU countries, more stringent regulations could foster comparative advantages at the international level for clean exports, and these findings could be interpreted as supporting evidence for the Porter hypothesis. Additionally, for exports of some goods belonging to dirty and footloose industries, we find some evidence of a PHE.

An important policy implication of our findings is that the differential in environmental stringency between exporting and importing countries is a significant factor in explaining the changes in trade patterns between countries. Stricter environmental regulations have the potential to enhance the distribution of environmentally safe, high-quality goods, services, and technology, thus lowering the pollution levels, reducing the depletion of natural resources, and improving health outcomes. Western countries should take the lead and 
spread the knowledge to developing countries. There are positive spillovers from investing in environmentally safe production that extend beyond the borders of a single country. In a related study, in an effort to reduce the greenhouse gas emissions, Gurtu, Searcy, and Jaber (2016) proposed a carbon tax based on the difference between emission rates of the importing and exporting countries since importing countries do not normally account for the emissions associated with the good they import. Therefore, they propose that countries adopt a carbon tax, as a national policy, on outsourced emissions. If adopted, this tax would be reflected in the total environmental tax revenue data used in our study. Adopting such a tax would prevent the relocation of pollution-intensive economic activities to countries with lax environmental regulations and prevent pollution havens from developing. To protect the integrity of the environment, necessary measures have to be taken domestically and internationally.

While our findings may apply only to the sample of countries studied, further research could be extended to include other countries that joined the EU beyond the original EU-15. Further analyses employing industry-specific measures of environmental stringency could shed additional light on the relationship between the environmental regulation and the trade patterns.

\section{Appendix}

Table AI. List of Industries and Classification.

\begin{tabular}{lllc}
\hline Code & \multicolumn{1}{c}{ Description } & Classification & Emissions intensity \\
\hline SITC 25I & Pulp and waste paper & Dirty & 0.608 \\
SITC 334 & Petroleum products & Dirty & 1.210 \\
SITC 335 & Residual petroleum products & Dirty & 2.743 \\
SITC 5I & Organic chemicals & Dirty & 0.967 \\
SITC 52 & Inorganic chemicals & Dirty & 2.331 \\
SITC 562 & Fertilizers & Dirty & 3.530 \\
SITC 59 & Chemical materials & Footloose & 1.019 \\
SITC 634 & Veneers, plywood & Dirty & 0.121 \\
SITC 635 & Wood manufactures & Dirty & 0.121 \\
SITC 64 & Paper, paperboard & Dirty & 0.608 \\
SITC 66I & Lime, cement, construction materials & Footloose & 12.01 \\
SITC 67 & Iron and steel & Footloose & 1.054 \\
SITC 68 & Non-ferrous metals & Dirty & 1.613 \\
SITC 69 & Metals manufactures & Footloose & 0.188 \\
\hline
\end{tabular}

Source. Classification from Harris et al. (2002). Emissions intensity is from ESA (2010). It is measured as metric tons of $\mathrm{CO}_{2}$ per $\$ 1,000$ in constant $\$ 2,000$. Also see http://www.esa.doc.gov/sites/default/files/ reports/documents/co2reportfinal.pdf. 
Table A2. List of Countries.

\begin{tabular}{lc}
\hline Country name & Year of accession \\
\hline Austria & \\
Belgium & 2007 \\
Bulgaria & 2004 \\
Czech Republic & \\
Denmark & \\
Finland & \\
France & \\
Germany & \\
Greece & \\
Hungary & 2004 \\
Ireland & \\
Italy & \\
Luxembourg & \\
Netherlands & \\
Poland & \\
Portugal & \\
Romania & \\
Slovakia & \\
Spain & \\
Sweden & \\
United Kingdom & \\
\hline Soure Auts & \\
& \\
\hline
\end{tabular}

Source. Author's elaboration.

Table A3. Definition of Variables and Sources.

\begin{tabular}{|c|c|c|}
\hline Variable & Definition of variables & Source \\
\hline Net $X_{i j k t}$ & $\begin{array}{l}\text { Net exports of industry } k \text { from country } i \text { to country } j \text { at } \\
\text { time } t\end{array}$ & Eurostat \\
\hline$Y_{i}$ & Country i Gross Domestic Product in current $€$ & Eurostat \\
\hline$Y_{j}$ & Country j Gross Domestic Product in current $€$ & Eurostat \\
\hline$E_{t a x d i f}$ & $\begin{array}{l}\text { Difference between the total environmental tax rev- } \\
\text { enues between countries } i \text { and } j \text { in current } €\end{array}$ & Eurostat \\
\hline EU & $\begin{array}{l}\text { Dummy that takes the value of I when countries } i \text { and } j \\
\text { are EU members }\end{array}$ & World Trade Organization \\
\hline
\end{tabular}




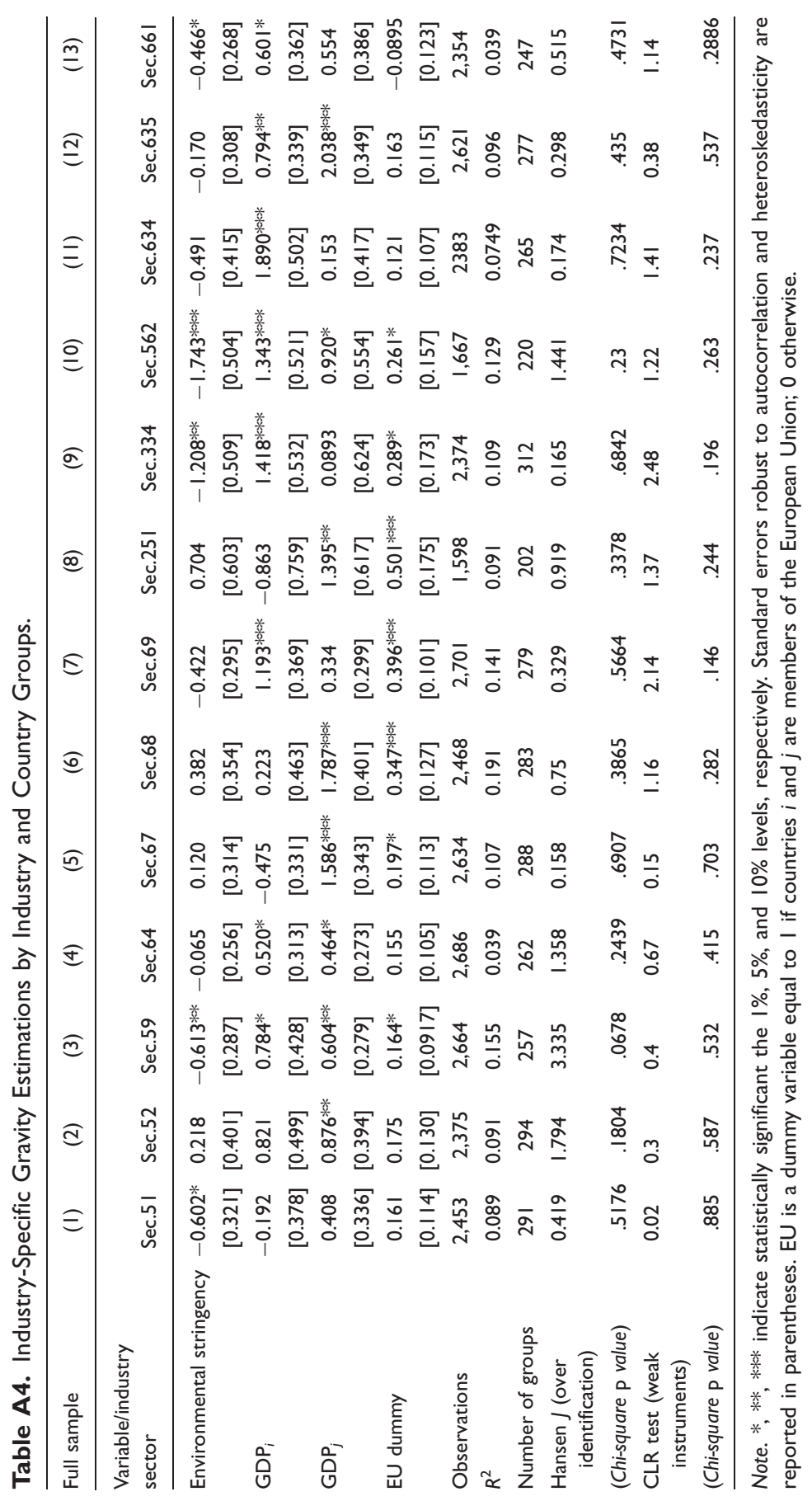




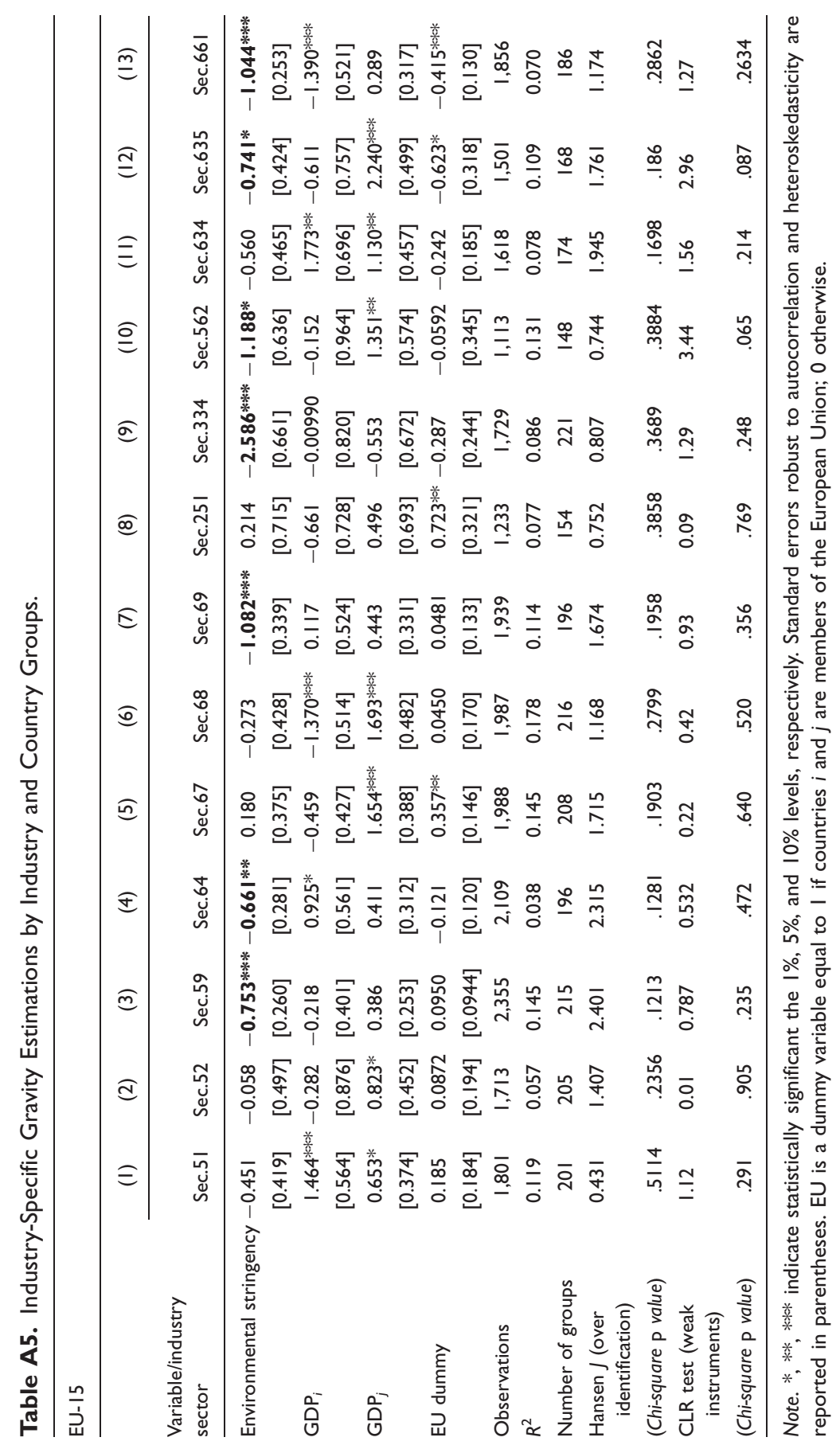




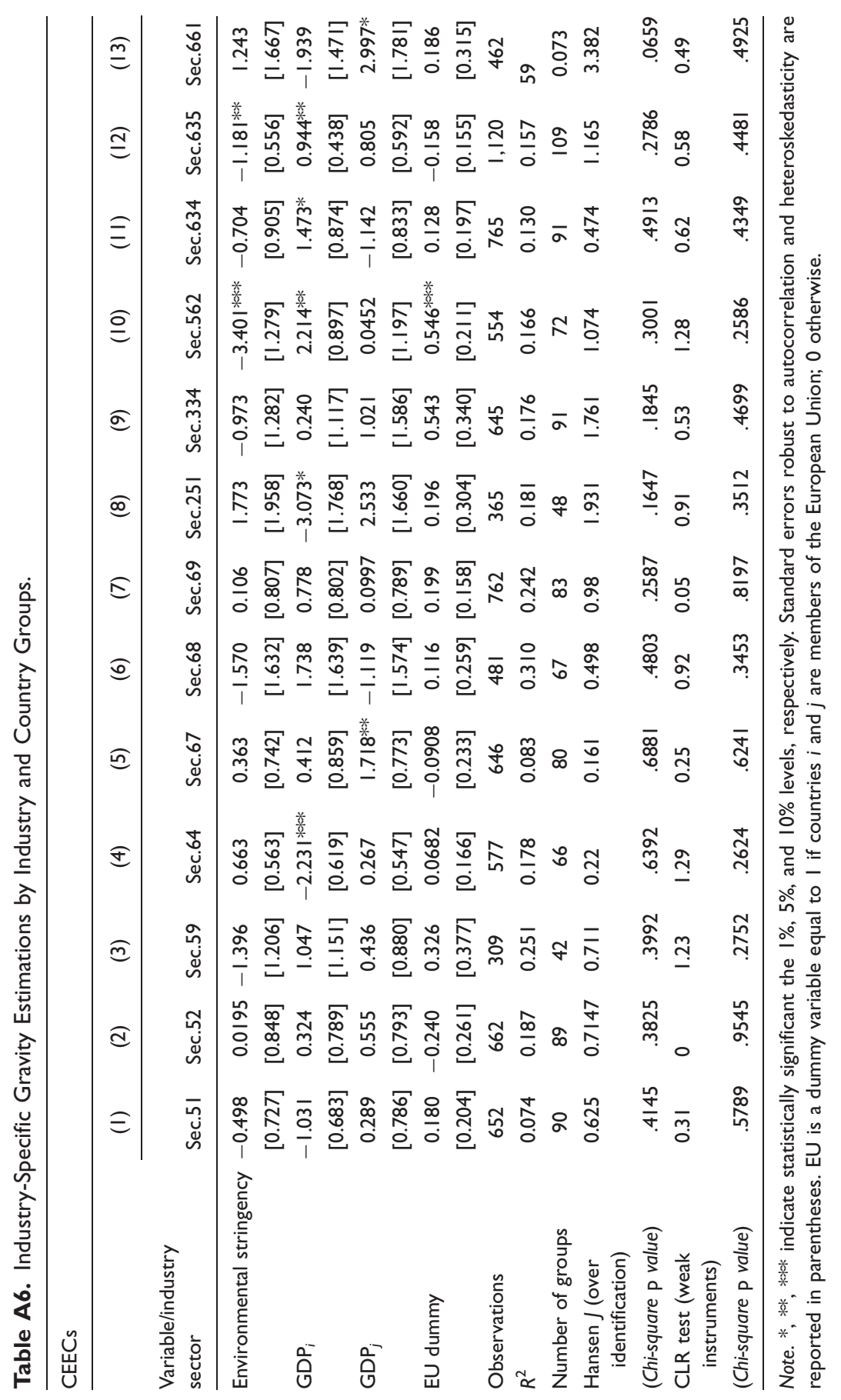




\section{Acknowledgments}

The authors also would like to thank two anonymous referees and the editor as well as the participants in the European Trade Study Group in Leuven for their helpful comments and suggestions.

\section{Declaration of Conflicting Interests}

The author(s) declared no potential conflicts of interest with respect to the research, authorship, and/or publication of this article.

\section{Funding}

The author(s) disclosed receipt of the following financial support for the research, authorship, and/or publication of this article: I. M.-Z. acknowledges the support and collaboration of Project ECO2014-58991-C3-2-R.

\section{Notes}

1. A few recent studies that found statistically significant PHE are Kellenberg (2009), Wagner and Timmins (2009), Levinson and Taylor (2008), and Ederington and Minier (2003). Jaffe et al. (1995) survey the earlier literature while Copeland and Taylor (2004) and Brunnermeier and Levinson (2004) present widely cited review of the relatively recent studies.

2. Footloose industries are industries that use very few raw materials and face low transportation costs since they do not have to locate near the sources of raw materials. Therefore, they can be easily moved from one country to another. Examples include high-tech industries such as computing.

\section{References}

Aichele, R., \& Felbermayr, G. (2012). Kyoto and the carbon footprint of Nations. Journal of Environmental Economics and Management, 63(3), 336-354.

Albrecht, J. (1998). Environmental costs and competitiveness. A product-specific test of the porter hypothesis. (Working Paper no. 50). Ghent, Belgium: University of Ghent.

Ambec, S., \& Barla, P. (2006). Can environmental regulations be good for business? An assessment of the Porter hypothesis. Energy Studies Review, 14(2), 42-62.

Ambec, S., Cohen, M. A., Elgie, S., \& Lanoie, P. (2011). The porter hypothesis at 20: Can environmental regulation enhance innovation and competitiveness? (Discussion Papers dp-11-01). Washington, DC: Resources for the Future.

Anderson, J. E. (1979). A theoretical foundation for the gravity equation. American Economic Review, 69, 106-116.

Anderson, J. E., \& Van Wincoop, E. (2003). Gravity with gravitas: A solution to the border puzzle. American Economic Review, 93, 170-192.

Antweiler, W., Copeland, B. R., \& Taylor, M. S. (2001). Is free trade good for the environment? American Economic Review, 91(4), 877-908.

Arouri, M. E. H., Caporale, G. M., Rault, C., Sova, R., \& Sova, A. (2012). Environmental regulation and competitiveness: Evidence from Romania. Ecological Economics, 81, 130-139. 
Ben Kheder, S., \& Zugravu, N. (2012). Environmental regulations and French firms location abroad: An economic geography model in an international comparative study. Ecological Economics, 77, 48-61.

Bergstrand, J. H. (1985). The gravity equation in international trade: Some microeconomic foundations and empirical evidence. The Review of Economics and Statistics, 67, 474-481.

Brunel, C., \& Levison, A. (2016). Measuring the stringency of environmental regulations. Review of Environmental Economics and Policy, 10(1), 47-67.

Brunnermeier, S. B., \& Levinson, A. (2004). Examining the evidence on environmental regulations and industry location. Journal of the Environment and Development, 13, 6-41.

Cole, M. A. (2004). Trade, the pollution haven hypothesis and the environmental kuznets curve: Examining the linkages. Ecological Economics, 48, 71-81.

Cole, M. A., \& Elliott, R. J. R. (2003). Determining the trade-environment composition effect: The role of capital, labor and environmental regulations. Journal of Environmental Economics and Management, 46(3), 363-83.

Cole, M. A., Elliott, R. J. R., \& Shimamoto, K. (2005). Why the grass is not always greener: The competing effects of environmental regulations and factor intensities on US specialization. Ecological Economics, 54, 95-109.

Constantini, V., \& Crespi, F. (2008). Environmental regulation and the export dynamics of energy technologies. Ecological Economics, 66, 447-460.

Copeland, B. R., \& Taylor, M. S. (2004). Trade, growth and the environment. Journal of Economic Literature, 42(1), 7-71.

Dean, J. M., Lovely, M. E., \& Wang, H. (2009). Are foreign investors attracted to weak environmental regulations? Evaluating the evidence from China. Journal of Development Economics, 90(1), 1-13.

Ederington, J., Levinson, A., \& Minier, J. (2005). Footloose and pollution-free. Review of Economics and Statistics, 87(1), 92-99.

Ederington, J., \& Minier, J. (2003). Is environmental policy a secondary trade barrier? An empirical analysis. Canadian Journal of Economics, 36, 137-154.

Esty, D., \& Geradin, D. (1998). Environmental protection and international competitiveness: A conceptual framework. Journal of World Trade, 32(3), 5-46.

Grether, J.-M., \& de Melo, J. (2003). Globalization and dirty industries: Do pollution havens matter? (NBER Working Paper Series, 9776). Cambridge, MA: NBER.

Grossman, G. M., \& Krueger, A. B. (1991). Environmental impacts of the North American free trade agreement (Working Paper 3914). Cambridge, MA: NBER.

Gurtu, A., Searcy, C., \& Jaber, M. Y. (2016). A framework for reducing global manufacturing emissions. Journal of Environment \& Development, 25(2), 159-195.

Harris, M. N., Kónya, L., \& Mátyás, L. (2002). Modelling the impact of environmental regulations on bilateral trade flows: OECD, 1990-1996. The World Economy, 25(3), $387-405$.

Jug, J., \& Mirza, D. (2005). Environmental regulations in gravity equations: Evidence for Europe. The World Economy, 28(11), 1591-1615.

Kellenberg, D. (2009). An empirical investigation of the pollution haven effect with strategic environment and trade policy. Journal of International Economics, 78(2), $242-255$. 
Khan, M., \& Yoshino, Y. (2004). Testing the pollution havens inside and outside of regional trading blocs. Advances in Economic Analysis \& Policy, 4(2), Article 4.

Levinson, A., \& Taylor, M. S. (2008). Unmasking the pollution haven effect. International Economic Review, 49(1), 223-254.

Lopez, R. E., \& Islam, A. F. (2008). Trade and the environment (Working Paper, WP 0814). College Park: Department of Agricultural and Resource Economics, University of Maryland. Retrieved form http://purl.umn.edu/45982

Low, P., \& Yeats, A. (1992). Do dirty industries migrate? In P. Low (Ed.), International trade and environment (World Bank Discussion Papers 159, pp. 29-52). Washington, DC: The World Bank.

Magnani, E. (2000). The environmental Kuznets curve, environmental protection policy and income distribution. Ecological Economics, 32(3), 431-443.

Manderson, E., \& Kneller, R. (2012). Environmental regulations, outward FDI and heterogeneous firms: Are countries used as pollution havens. Environmental and Resource Economics, 51(3), 317-352.

Mani, M., \& Wheeler, D. (1997). In search of pollution havens? Dirty industry migration in the world economy (World Bank Working Paper 16). Washington, DC: The World Bank.

Mantovani, A., \& Vancauteren, M. (2008). Environmental policy and trade in the single market. Emerging Markets Finance and Trade, 44(3), 34-47.

Marconi, D. (2012). Environmental Regulation and Revealed Comparative Advantages in Europe: Is China a Pollution Haven?. Review of International Economics, 20, 3616-635.

Mathys, N. (2002). In search of evidence for the pollution haven hypothesis. Mémoire de Licence, Université de Neuchâtel.

Mulatu, A., Florax, R., \& Withagen, C. (2004). Environmental regulation and international trade: Empirical results for Germany, the Netherlands and the US, 1977-1992. Contributions to Economic Analysis \& Policy, 3(2), 1276.

Murty, M. N., \& Kumar, S. (2003). Win-win opportunities and environmental regulation: Testing of porter hypothesis for Indian manufacturing industries. Journal of Environmental Management, 67(2), 139-144.

Pearce, D., \& Palmer, C. (2001). Public and private spending for environmental protection: A cross-country policy analysis. Fiscal Studies, 22(4), 403-56.

Porter, M. E., \& van der Linde, C. (1995). Toward a new conception of the environmentcompetitiveness relationship. Journal of Economic Perspectives, 9(4), 97-118.

Rezza, A. A. (2013). FDI and pollution havens: Evidence from the Norwegian manufacturing sector. Ecological Economics, 90, 140-149.

Spatareanu, M. (2007). Searching for pollution havens: The impact of environmental regulations on foreign direct investment. The Journal of Environment and Development, 16, 161-182.

Stoessel, M. (2001). Trade liberalization and climate change. Geneva, Switzerland: The Graduate Institute of International Studies.

Tobey, J. A. (1990). The effects of domestic environmental policies on patterns of world trade: An empirical test. Kyklos, 43(2), 191-209.

U.S. Department of Commerce Economics and Statistics Administration U.S. Carbon Dioxide Emissions and Intensities Over Time: A Detailed Accounting of Industries, Government and Households, April 2010. 
van Beers, C., \& van den Bergh, J. C. M. (1997). An empirical multi-country analysis of the impact of environmental regulations on foreign trade flows. Kyklos, 50, 29-46.

Wagner, U., \& Timmins, C. (2009). Agglomeration effects in foreign direct investment and the pollution haven hypothesis. Environmental and Resource Economics, 43, $231-256$.

Xu, X. (1999). Do stringent environmental regulations reduce the international competitiveness of environmentally sensitive goods? A global perspective. World Development, 27, 1215-1226.

$\mathrm{Xu}, \mathrm{X}$. (2000). International trade and environmental regulations: Time series evidence and cross section tests. Environmental and Resource Economics, 17(3), 233-257.

\section{Author Biographies}

Inmaculada Martínez-Zarzoso is Professor of Economics at the University of Göttingen, Germany. She received her PhD in Economics from the University of Birmingham, UK, and currently holds a professorship at the Jaume I University, Spain. She has published extensively in international peer-reviewed journals such as the Journal of International Economics, Review of International Economics and Journal of Common Market Studies.

Martina Vidovic is Associate Professor of Economics at Rollins College, USA. She was awarded her PhD in Economics from SUNY Binghamton University, USA. Her research and publications focus on evaluating voluntary pollution prevention programs, corporate environmental sustainability as well as associations between pollution and trade.

Anca M. Voicu is Associate Professor of Economics at Rollins College, USA. She was awarded her PhD in Economics from the University of Birmingham, UK, and previously studied at the Academy of Economic Studies in Bucharest, Romania. Her research interests and publications are mainly focused on area studies with an emphasis on Central and Eastern European economies, trade modelling and forecasting and environmental economics. 